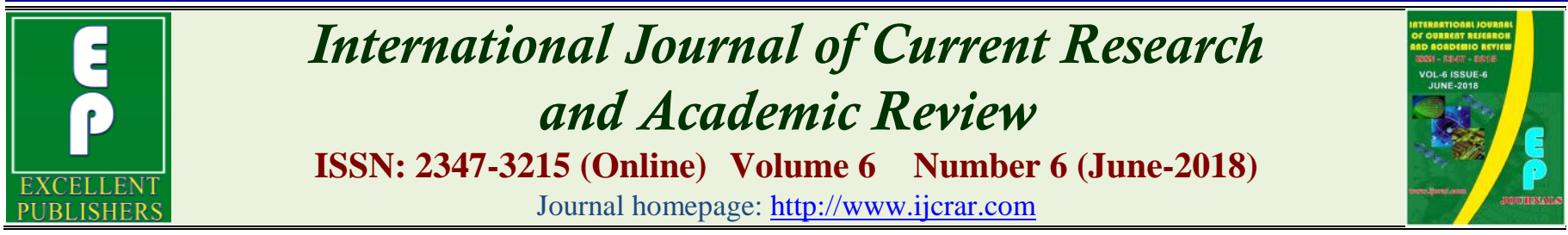

doi: https://doi.org/10.20546/ijcrar.2018.606.006

\title{
Assessment of Fresh Water Quality Using a Gastropod Snail Indoplanorbis exustus (Dehayes, 1834) Mollusca: Pulmonata
}

\author{
M. Kavitha ${ }^{1 *}$, H.M. Mahilini ${ }^{2}$ and Albert Rajendran ${ }^{2}$ \\ ${ }^{1}$ Research Department of Zoology, Sri Parasakthi College for Women, Courtallam, Tamil Nadu, India - 627802 \\ ${ }^{2}$ Research Department of Zoology, St.John's College, Palayamkottai, Tamil Nadu, India - 627002 \\ *Corresponding author
}

\section{Abstract}

Freshwater gastropod snail Indoplanorbis exustus is a highly tolerant organism to stressors and can thrive well in polluted waters. Even healthy gastropod snails concentrate bacteria in their body and can act as reservoirs of pathogens, and this character indicates that the snails act as bioindicator of pathogenic organisms, which they harbor through the aquatic environment. An attempt has been made to investigate the total number of bacterial colonies and the density of each bacterial isolate in the body fluid (hemolymph) of healthy Indoplanorbis exustus to highlight the fact that this Freshwater gastropod snail could be a tool as an environmental microbial bio-indicator. The results indicate a mean total density of bacterial species that have been isolated from the hemolymph. Among the six isolates, the density of Escherichia coli was the maximum ranging from $3.2 \times 10^{4}$ to $2.20 \times 10^{6} \mathrm{CFU} / \mathrm{ml}$ and the lowest record was of Pseudomnas spp., ranging from $9 \times 10^{3}$ to $6.8 \times 10^{5} \mathrm{CFU} / \mathrm{ml}$. This finding reveals that $\mathrm{FW}$ gastropod snails such as Indoplanorbis exustus could be a tool for bacterial indicators in monitoring water quality in polluted environments.
\end{abstract}

\section{Article Info}

Accepted: 28 May 2018

Available Online: 20 June 2018

\section{Keywords}

Indoplanorbis exustus, Water quality, Bacterial bio-indicators.

\section{Introduction}

Gastropod species are among the most biologically used indicators to assess the quality of any water impoundment. Many benefits have been derived from freshwater resources. They provide drinking water resource, water resources for Agriculture Industry, Sanitation and home to numerous organisms namely aquatic plants, invertebrates and vertebrates. Molluscan communities are good indicators of localized conditions (Rajendra et al., 2004). Freshwater gastropods are tolerant organisms to stressors and they can be used as bacterial indicator to assess the water quality of that environment.
Molluscs - bacteria interactions occur in natural conditions since bacteria constitute an important part of the micro flora of the environment (Oubella et al., 1994). Gastropod molluscs accumulate large number of gram positive and gram negative microorganisms in the hemolymph and tissues (Colwell and Liston, 1962; Murchelano and Brown, 1968). More over snails satisfy all the condition of a good biological indicator (Hella Well, 1986; Hopkin, 1993). Kolkwitz and Morsson, (1909) showed that the concept of biological indicators of environmental condition originated of saprobity (the degree of pollution)in rivers as a measure of the degree 
of contamination by organicmatter and the resulting decrease in dissolved oxygen.

The present work has been carried out in the freshwater gastropod Indoplanorbis exustus which lives in ponds and lakes. They can thrive well in polluted waters (Sinha, Chatterjee and Chattopadhyay, 2010). An attempt has been undertaken to investigate the total number of bacterial colonies and number of each bacterial isolate $(\mathrm{CFU} / \mathrm{ml})$ in the body fluid (hemolymph)of the mollusc to elucidate the environmental health of the water system.

\section{Materials and Methods}

The gastropods I.exustus was collected from their natural habitats in and around Tirunelveli District (Alt 125ft, Lat, $77^{\circ} 47^{\prime}$ and long $8^{\circ} 30^{\prime}$ N) Tamil Nadu, South India and brought to the laboratory).

\section{Hemolymph Sampling}

Hemolympth sampls were collected from I.exustus, upon severe touching of the foot it retracted very deeply into its shell and extruded several drops of red coloured blood as shown by Sminia and Barendsen (1980)

Enumeration of Bacteria is done in the body fluid (hemolymph) and collected by plate count method $(\mathrm{CFU} / \mathrm{ml})$.

The bacterial population was indentified through biochemical tests and cultural characteristics of the organisms. The density of each bacterial isolate has also been enumerated.

\section{Results and Discussions}

Gastropod snails concentrate bacteria in its body and it could act as a reservoir of pathogen (Malek and Cheng ,1974; Suresh and Mohandoss, 1990). It can act as vectors for the spread of certain diseases that are pathogenic for human such as Vibriocholerae, Vibrio vulnificaus and Vibriopara hemdyticus (Colwell, 1984; Tamplin et al., 1982; Tamplin and capers, 1992). The present investigation revealed that the mean total number of bacterial colonics in the body fluid (hemolymph) ranges from $8.9 \times 10^{4}$ to $7.5-10^{6}(\mathrm{CFU} / \mathrm{ml})$.

Six species have been isolated from the hemolymph namely Staphylococcus spp, Bacillus spp, Klebsiella spp,
Escherichia coli, Enterobactor spp. out of six isolates to species were gram-positive (Staphylococcus spp and Bacillus spp and four were gram - negative (E.coli, Klebsiella spp, Enterobacter spp and Pseudomonas spp) (Table.1).

Among the six isolates the density of E.Coli has maximum record ranging from $3.2 \times 10^{4}$ to $2.2 \times 10^{5}$ $(\mathrm{CFU} / \mathrm{ml})$ and lowest record of Pseudomonas spp which ranges from $9 \times 10^{3}$ to $68 \times 10^{4}(\mathrm{CFU} / \mathrm{ml})$. Vibrio and Pseudomonas species are normal constitements of the microflora of healthy molluscs (Olafsen et al; 1993). The present investigation of bacterial indicator test highest density of Escherichia coli in the body fluid (hemolymph) of I. exustus which may indicate that the presence of fecal Coliform bacteria in the aquatic environment where these snails are found. The presence of fecal coliform in aquatic environment may indicate that the water has been contaminated with fecal material of humans or other animals (wikipedia org/wki/indicatorbacteria) (en.wikipedia.org).If the number fecal...

These concepts have been applied to the identification of indicator species assembles in the Northwestern United states (Whittier et.al., 1988 in Arkanses). Kolkmitz and Marson (1909) showed that the concept of biological indicators of environmental contamination originated the idea of saprobity (the degree of pollution) in rivers as a measure of the degree of contamination by organic matter and the resulting decrease in dissolved oxygen, and the number of fecal coliform bacteria (over 200 colonies / 100ml of water sample. High fecal coliform counts causes diseases include typhoid fever, hepatitis, gastroenteritis, dysentery and ear infections.

Fecal coliform by themselves are usually not pathogenic, they are indicator organisms, which means they may indicate the presence of other pathogenic bacteria. In general increased level of fecal coliform provide warning of possible contamination with pathogens. The goal of these new efforts is to understand the native fauna and manage waters to maximize biological quality.

The other bacterial isolates recorded in the body fluid (hemolymph) indicate the presence of such pathogens in the aquatic environment where these gastropod snail inhabit in that water. This character indicate that Indoplanorbis exustus could be used as bacterial indicators in monitoring the quality of water. 
Table.1 The bacterial concentrations of each bacterial isolates

\begin{tabular}{|c|l|l|l|}
\hline S.No. & \multicolumn{1}{|c|}{ Name of the isolates } & $\begin{array}{c}\text { Gramstaining Positive } \\
\text { / Negative }\end{array}$ & $\begin{array}{c}\text { Mean number of } \\
\text { colonies found in the } \\
\text { hemolymph } \text { (CFU/ml) }\end{array}$ \\
\hline 1. & Staphylo coccus spp & Positive & $6 \times 10^{3}-8.0 \times 10^{5}$ \\
\hline 2. & Bacillus spp & Positive & $1.4 \times 10^{4}-9.2 \times 10^{5}$ \\
\hline 3. & Klebsiella spp & Negative & $1.2 \times 10^{4}-1.0 \times 10^{6}$ \\
\hline 4. & Escherichia coli & Negative & $3.2 \times 10^{4}-2.2 \times 10^{6}$ \\
\hline 5. & Enterobacter spp & Negative & $1.6 \times 10^{4}-1.9 \times 10^{6}$ \\
\hline 6. & Pseudomonas spp & Negative & $9 \times 10^{3}-6.8 \times 10^{5}$ \\
\hline
\end{tabular}

Mean for 25 samples

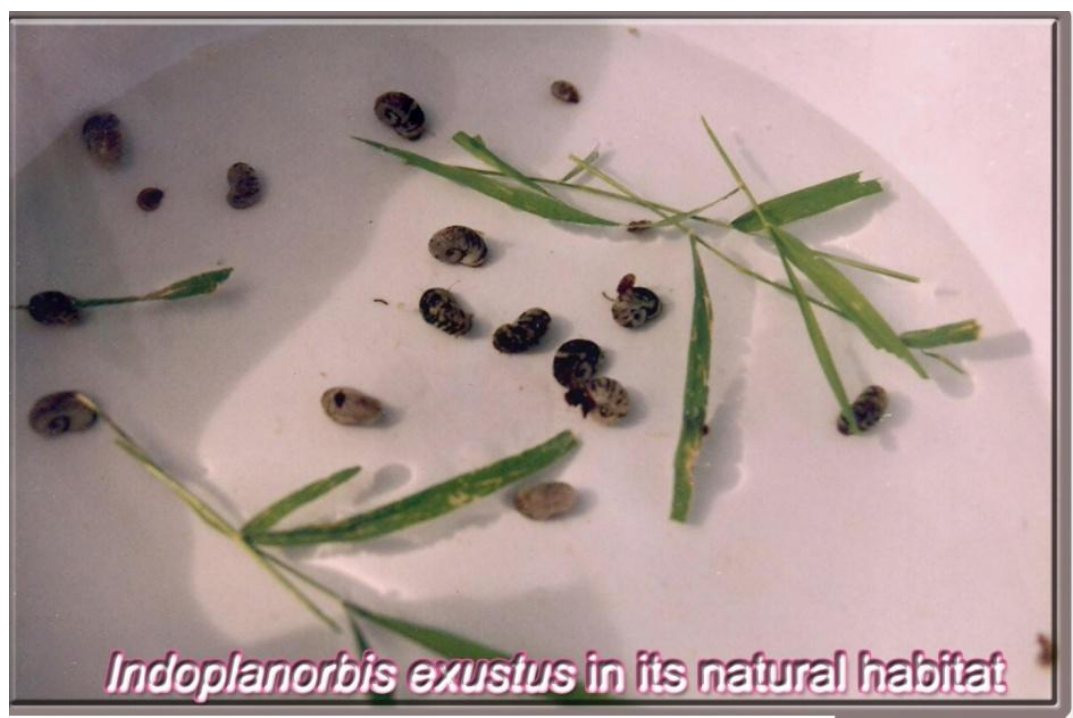

Bacterial Colonies of Indoplanorbis exustus in the Hemolymph
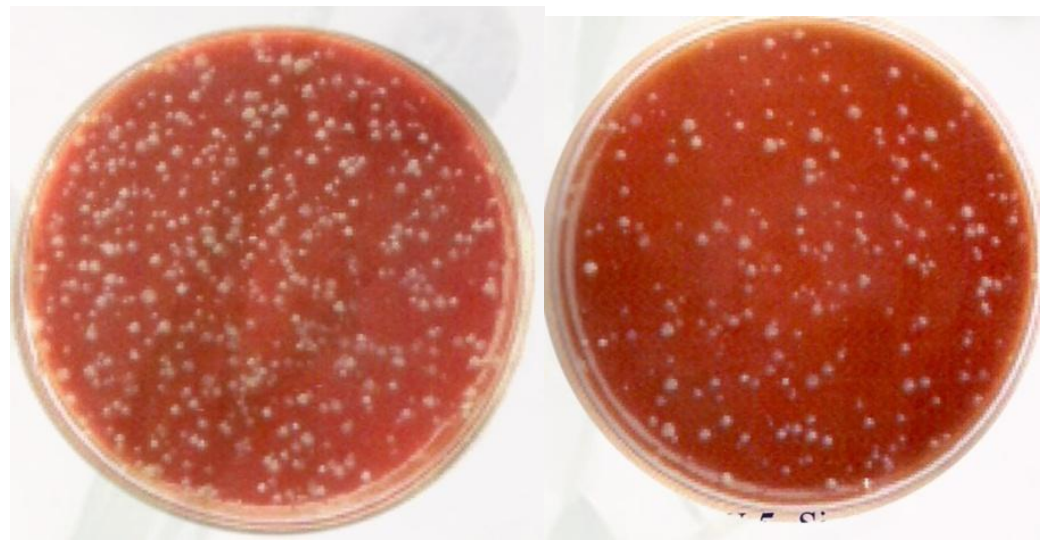


\section{Conclusion}

Towards an environment with less pollution which should be considered essential for quality assurance of a healthy life on our planet, it is necessary to develop systems able to detect even low concentrations of pollutants in the eco systems and evaluate their effects on natural populations. With this, standards can then be established for a safe release of these substances in freshwater systems in order to attain and keep the good quality of water supplies and preservation of these eco systems.

The development of new tests with species of environmental relevance is necessary to improve the condition of polluted areas and to conserve less distributed areas.

Among the next steps that should be taken is this standardization of these assays by the regulatory agencies the gathering of all available information and the promotion of its dissemination as well as the wide use of these essays in environmental analysis. Further studies encompassing field and laboratory observation on the eco-biology of the species need to be undertaken from different localities.

\section{References}

Cappuccino, B.J.B and Sherman, N.1999. Microbiology. A laboratory manual, fourth edition, Addition Wesley Longman Publications 59-186.

Colwell, R.R. and Liston, J.1962. The natural bacterial flora of certain marine invertebrates. J.Insect. Pathol., 4: 23-33.

Colwell, R.R 1984. Vibrios in the environment. John Wiley, New York Murchelano, R.A. and Brown, C.1968. Bacteriological study of the natural flora of Eastern Oyster, Crassostrea virginica. J.Invertebr. Pathol., 11:519-520.

Hellawell, J.M.1986. Biological indicators of freshwater pollution and environmental management. Elsevier Applied Science, London.

\section{How to cite this article:}

Kavitha, M., H.M. Mahilini and Albert Rajendran. 2018. Assessment of Fresh Water Quality Using a Gastropod Snail Indoplanorbis exustus (Dehayes, 1834) Mollusca: Pulmonata. Int.J.Curr.Res.Aca.Rev. 6(6), 49-52. doi: https://doi.org/10.20546/ijcrar.2018.606.006
Hopkins, S.P.1993. Insita biological monitoring of pollution in terrestrial and aquatic ecosystems, In. Hand book of ecotoxicology, Calow, p.(ed) Blackwell Scientific, PP.397-427.

Kolkwitz, R. and M.Marson 1909. Okologic der tier is chen saprobe en- International Revue der Gesamien Hydrobiologie and Hydrographic 2:126-52.

Malek, E.A. and Cheng, T.C.1974. Medical and Economic Malacology. New York and London, Academic Press.

Murchelano, R.A. and Brown, C.1968. Bacteriological study of the natural flora of Eastern Oyster, Crassostrea virginica. J.Invertebr, Pathal., 11:519-520.

Olasfsen, J.A., Mikkelsen, H.V., Giever, H.M. and Hansen, G.H.1993. Indigenous Bacteria in Hemolymph and Tissues of Marine Bivalves at Low Temperatures. App.Environ. Microbiol., 59:1848-1854.

Oubella, R., Pailard, C., Maes, P. and Auffret, M. 1994. Changes in hemolymph parameters in the Manila Clam Ruditapes phillippinarum (Mollusca: Bivalvia) following bacterial challenge. J.Invertebr. Pathol., 64:33-38.

Rajendra S.Mavinkurve, Sandhya P.Shanbhag and Madhyastha, N.A., 2004. Non marine mollusks of Western Ghats. A status Review. Zoo's Print Journal, 19(12): 1708-1711. en.wikipedia.org/wiki/indicator bacteria.

Suresh, K. and Mohandass, A.1990. Number and types of hemocytes in Sunetta scripta and Villortia cyprinoids var. Cochinensis (Bivalvia) and leukocytosis subsequent to bacterial challenge. J. Invertebr. Pathol., 55:312-318.

Sinha. J, Chatterjec, A.K and P.Chattopathyay, 2010. Planorbis, Advanced Practical Zoology. Books and Allied (P) Ltd., Kolkotta. PP 1034:80.

Tamplin, M.,Rodrick, G.E., Blake, N.J. and Cuba, T.1982. Isolation and characterization of Vibrio vulnificus from two Florida estuaries. Appl. Environ. Microbiol., 44:1466-1470.

Tamplin, M.L. and Capers, G.M.1992. Persistence of Vibrio vulnificus in tissues of Gulf coast oysters. Crassostrea virginica, exposed to seawater disinfected with uv light. Appl. Environ. Microbiiol., 58:1506-1510.

Whttier, R.Hughes, R.M.and David P.1988. Correspondence between ecoregiones and spatial patterns in stream ecosystems in Oregon. Canadian journal of fisheries and aquatic sciences 45 (7) 1264-1278. 